
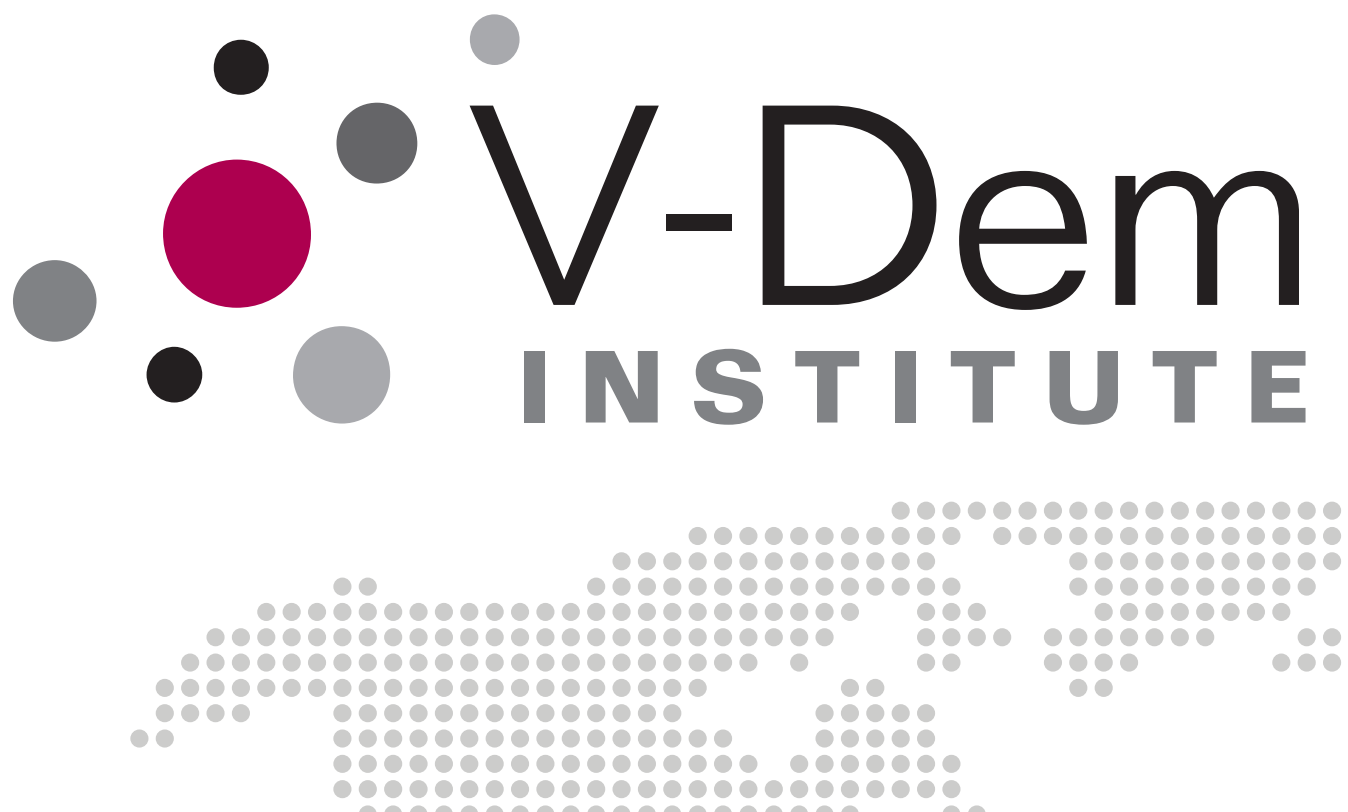 000900
100

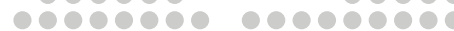

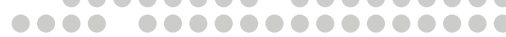

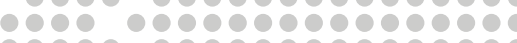

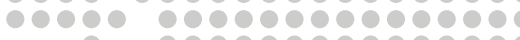
00

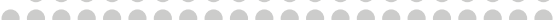

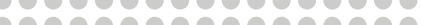

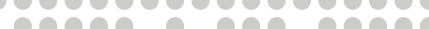

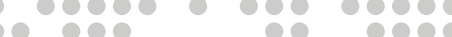
60

Neopatrimonialism and Democracy: An Empirical Investigation of Africa's Political Regimes

Rachel Sigman Staffan I. Lindberg
00000000

0000000

1000000

090000

10000

000

000

10

10

80

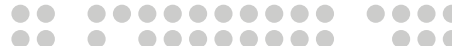

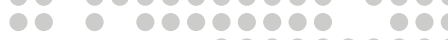

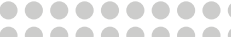

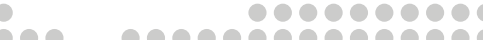

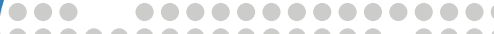

$000000000000000000 \mathrm{l}$

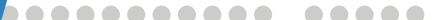

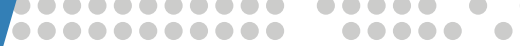

1000000000000000000

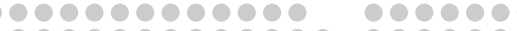

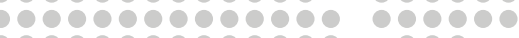
00000000000000 000000000000000

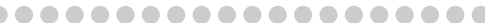
000000000000000000

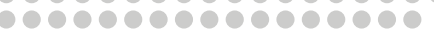

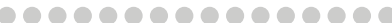

\%०000000000000

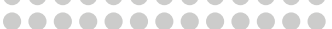

10000000000

00000000000

0000000000

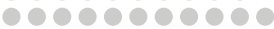

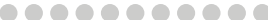

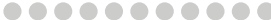

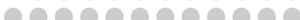

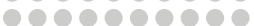

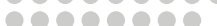

00000000

000000

100000

000000

1000

100

00 
Varieties of Democracy ( $\mathbf{V}-\mathbf{D e m})$ is a new approach to conceptualization and measurement of democracy. It is co-hosted by the University of Gothenburg and University of Notre Dame. With a V-Dem Institute at University of Gothenburg with almost ten staff, and a project team across the world with four Principal Investigators, fifteen Project Managers (PMs), 30+ Regional Managers, 170 Country Coordinators, Research Assistants, and 2,500 Country Experts, the V-Dem project is one of the largest ever social science research-oriented data collection programs.

Please address comments and/or queries for information to:

V-Dem Institute

Department of Political Science

University of Gothenburg

Sprängkullsgatan 19, PO Box 711

SE 40530 Gothenburg

Sweden

E-mail: contact@v-dem.net

V-Dem Working Papers are available in electronic format at www.v-dem.net. Copyright (C2017 by authors. All rights reserved. 


\title{
Neopatrimonialism and Democracy: An Empirical Investigation of Africa's Political Regimes*
}

\author{
Rachel Sigman \\ Naval Postgraduate School and V-Dem Institute, University of Gothenburg \\ Staffan I. Lindberg \\ V-Dem Institute, University of Gothenburg
}

November 6, 2017

${ }^{*}$ This research project was supported by Riksbankens Jubileumsfond, Grant M13-0559:1, PI: Staffan I. Lindberg, V-Dem Institute, University of Gothenburg, Sweden; by Knut and Alice Wallenberg Foundation to Wallenberg Academy Fellow Staffan I. Lindberg, Grant 2013.0166, V-Dem Institute, University of Gothenburg, Sweden; as well as by internal grants from the Vice-Chancellor's office, the Dean of the College of Social Sciences, and the Department of Political Science at University of Gothenburg. We performed simulations and other computational tasks using resources provided by the Notre Dame Center for Research Computing (CRC) through the High Performance Computing section and the Swedish National Infrastructure for Computing (SNIC) at the National Supercomputer Centre in Sweden, SNIC 2016/1-382 and 2017/1-68. We specifically acknowledge the assistance of In-Saeng Suh at CRC and Johan Raber at SNIC in facilitating our use of their respective systems. The indices of neopatrimonialism used in this paper will be available for public use in V-Dem's v8 dataset, set to be released in April 2018 at www.v-dem.net. 


\section{Abstract}

One of the most common adjectives used to describe democracy in sub-Saharan Africa is "neopatrimonial." Characterized by strong executives, pervasive clientelism and use of state resources for political legitimation (Bratton and van de Walle 1997), neopatrimonial democracy has been (controversially) associated with a range of (mostly undesirable) social, political and economic outcomes. This paper offers an empirical assessment of neopatrimonialism in Africa's political regimes. We show that, contrary to conventional wisdom, African regimes vary both quantitatively and qualitatively in their embodiment of neopatrimonial rule. Moreover, we find no clear evidence indicating that neopatrimonialism necessarily impedes the advancement or survival of democracy. 


\section{Introduction}

Amidst the 'Third Wave' of democratization, Collier and Levitsky famously warned of the "growing scholarly confusion" resulting from the proliferation of concepts related to democracy, or what they call "democracy with adjectives" (Collier and Levitsky, 1997). While the literature on democracy in sub-Saharan Africa ${ }^{1}$ has certainly contributed its share of new adjectives, one adjective in particular has dominated theoretical discussions surrounding regime trajectories on the continent: neopatrimonial.

Neopatrimonial rule, in Africa or elsewhere, combines strong presidents, clientelistic linkages between citizens and politicians, and the use of state resources for political legitimation (Bratton and Van de Walle, 1997). These features may be present across different regime types, from highly competitive democracies to highly closed authoritarian regimes. They may be embedded in formal political rules, such as the Ghanaian president's constitutional right to appoint every mayor in the country, or they may reflect less formal practices such as political favoritism in the distribution of state resources.

While the notion of strong presidents engaging in patronage-based distribution of resources and eschewing institutional constraints to their power seems highly inimical to the idea of democratic rule, Africa, perhaps more than any other region, provides strong evidence that neopatrimonialism does not necessarily hinder the adoption or survival of democratic institutions. In fact, there is now considerable evidence that democratization, even in neopatrimonial contexts, can bring about expansions in civil rights and political freedoms (Lindberg, 2006; Edgell et al., 2017), the institutionalization of constitutional rule (Posner and Young, 2007), improvements in governance (Alence, 2004) and wider distributions of public goods and services (Stasavage, 2005; Burgess et al., 2015). Moreover, some have argued that patrimonialism may actually promote both democracy (Pitcher et al., 2009) and developmental governance (Crook, 1989; Booth and Golooba-Mutebi, 2012; Kelsall, 2013).

The main goal of this paper is to delineate to what extent, and in what specific ways, African regimes live up to their neopatrimonial reputation. To do so, we develop a multidimensional measure of neopatrimonialism that enables us to explore the varying ways that neopatrimonialism manifests itself in political regimes across Africa, and the extent to which 'neopatrimonial rule' acts as an actual impediment to democracy.

Our investigation reveals several important problems with common assumptions about neopatrimonialism in African political regimes. First, we find that, on average, regimes in Africa are not considerably more neopatrimonial than those of other regions of the developing world. Second, there is a large amount of variation in neopatrimonialism across African

\footnotetext{
${ }^{1}$ Hereafter, we use "Africa" to mean "sub-Saharan Africa"
} 
political regimes both in terms of the level of neopatrimonialism across countries and the specific configurations of the three main dimensions of neopatrimonial rule. Finally, we show that neopatrimonialism does not act as a particularly strong or consistent impediment to the advancement or survival of democracy. Together, these observations suggest the need to further question widespread assumptions about the exceptional, undemocratic qualities of neopatrimonial rule in Africa.

\section{Democracy with One Adjective}

Both states and politics in Africa are commonly described as neopatrimonial. At its broadest level, this term reflects the idea that patrimonial forms of authority permeate modern institutional structures. In patrimonial contexts, the right to rule is vested in the person; and the legitimacy of this person's authority is derived from popular acceptance of the norms, customs or beliefs commonly associated with traditional familial or household structures (Weber, 1946). Unlike rational-legal authority, which is based on impersonal, formally proscribed or natural laws, patrimonial authority vests the power to rule in a specific individual. Patrimonialism is also distinct from Weber's notion of charismatic authority, which is based not on law, custom or tradition, but on the perception that a leader has some extraordinary ability to rule. A patrimonial system is "held together by the oath of loyalty, or by kinship ties (often symbolic and fictitious) rather than by a hierarchy of administrative grades and functions" (Clapham, 1985, 48).

Neopatrimonialism differs from patrimonialism in at least two important ways. First, the most basic distinction is the presence of institutions with the 'trappings' of modern, legalrational institutions (Bratton and Van de Walle, 1997), even if authority remains highly personalized (Clapham, 1985; Eisenstadt, 1973; Zolberg, 1966). As Clapham explains, "officials hold positions in bureaucratic organizations with powers which are formally defined, but exercise those powers, so far as they can, as a form not of public service but of private property" (1985, 48).

Second, the traditional basis of patrimonial authority may be less pronounced in neoapatrimonial settings than in more purely patrimonial ones (Roth, 1968). Rather than practicing loyalty, tribute or reciprocity, all of which tend to be rooted in shared customs or beliefs, practices in neopatrimonial settings may take on a more transactional character. As Erdmann and Engel (2007) note, this transactional nature of power effectively divorces patrimonialism from the economic or political contexts (i.e. feudalism) in which specific sets of customs and traditional beliefs were theorized to drive such relationships. To this end, Scott's (1972) account of the decline of more traditional, longstanding patron-client relationships in the 
face of modernization and democratization in Southeast Asia resonates with the way that many contemporary scholars tend to view neopatrimonialism.

Although the concept of neopatrimonialism is used widely throughout scholarship on the politics and development of Africa (and elsewhere), it has not gone uncriticized. As a number of pieces have persuasively argued, the concept is deployed so broadly that it tends to cloud the large variation in economic and political outcomes across the continent (Pitcher et al., 2009; Bach, 2011; Mkandawire, 2015; Crook, 1989; Theobald, 1982). Contrary to the dominant perspectives, these works show how neopatrimonialism can be a force for democracy, social cohesion, redistribution, administrative effectiveness and development. Likewise, increasing attention to 'developmental' forms of patrimonialism in places like Rwanda (Kelsall, 2013; Booth and Golooba-Mutebi, 2012) and Angola (Croese, 2017) are helping to challenge the more conventionally negative views of the concept.

\section{Neopatrimonial Democracy?}

When, in the 1990s, the Third Wave of democratization reached sub-Saharan Africa, the concept of neopatrimonialism was rather quickly adopted to explain why both transitions and the resulting regimes appeared, in a number of ways, different from those of other regions of the world (Bratton and Van de Walle, 1997). In many cases, the adoption of the neopatrimonial adjective to describe African democracy was accompanied by pessimism about both its depth and durability. Many concluded that changes in formal political institutions were unlikely to fundamentally transform the deep-seated structures feeding the "politics of the belly'(Bayart, 1993) and entrenched forms of 'personal rule' (Jackson and Rosberg, 1982) in most, if not all, African countries. "The advent of elections," as (Bratton and Van de Walle, 1997, 9) wrote, "marked a scramble for political positions and an intensification of tendencies to quickly make the most of the benefits of office-holding." In short, in focusing on the neopatrimonial character of newly installed democratic regimes, many predicted a quick return to the chaotic and often predatory 'big men' politics that dominated the 1970s and 1980s (Schatzberg, 2001), since this is what "works" in Africa (Chabal and Daloz, 1999).

This sense of pessimism about regime change in Africa was based on a set of ideas suggesting that, in neopatrimonial contexts, personalistic authority is, by nature, at odds with the workings formal democratic institutions. One path to this conclusion runs through O’Donnell's (1993) observations about democracy in Latin America suggesting that "systems of privatized power" operating in so-called "brown spots" render ineffective the "rights and guarantees of democratic legality" (O'Donnell, 1993, 1359). Such conditions constitute fertile ground for anti-system movements and can seriously reduce the prestige and author- 
ity of democratic leaders $(1993,1365)$. Many concluded that such dynamics lead to weak democratic regimes that are easily toppled by various types of challengers. Such was the case, for example, in Joseph's account of 'prebendal' democracy in Nigeria (Joseph, 1987).

Another perspective emphasizes the ways that patrimonial authority enables leaders, especially presidents, to undermine the checks and balances typically associated with democratic rule. By monopolizing access to resources, incumbents co-opt or coerce the opposition, thereby tilting the political playing field to their advantage (Van de Walle, 2003). To the extent that leaders do so in a way that seriously undermines free and fair competition, we are likely to see a reversion to, or persistence of, electoral authoritarian regimes. ${ }^{2}$ While a number of studies have shown that leaders can be quite successful in pursuing such strategies (Joseph, 2008; Van Cranenburgh, 2008), there is considerable variation in the extent to which presidents in African countries have both tried to pursue this strategy; and been successful in doing so. In some cases, legislative or judicial institutions have exerted serious constraints on such efforts (Opalo, 2012; VonDoepp, 2005); while in other cases popular uprising, fueled by the 'movement legacy' of African politics, has played an important role (Cheeseman, 2015).

Although there is no shortage of anecodotes to substantiate these theorized links between neopatrimonialism and some of the more tenuous patterns of democracy observed in Africa, it is surprising that the widely predicted negative effects of neopatrimonial rule on the durability of democracy are not observed more widely. What earlier observers of democracy in Africa may have missed is that both the global and domestic contexts in which new democratic regimes were operating had changed in important ways. The end of the Cold War was particularly consequential. Western aid flowed more freely to African countries and donors were now able to make credible threats of democratic conditionality (Dunning, 2004), even if they did not actually follow-through in practice. At the same time, greater 'linkage' to the West (Levitsky and Way, 2005) in the form of trade, communication and transnational NGO networks reinforced democratic norms and ideals among both citizens and elites. Thus, even if democratic legal authority was weaker than in Western contexts, international support for such authority had become stronger.

At the domestic level, structural conditions became more favorable to democracy as well. Economies began growing again in the 1990s and the proportion of populations living in cities in sub-Saharan Africa grew from about $18 \%$ in the 1970 s to over $30 \%$ in the late 1990s (World Bank, 2017). With help from international donors, advances in average years of schooling (Barro and Lee, 2013) and key health indicators also rose. ${ }^{3}$ While researchers are

\footnotetext{
${ }^{2}$ On trends in electoral authoritarianism in Africa, see Morse (2012) and (Lynch and Crawford, 2011, 281) for overviews.

${ }^{3}$ While we can not, of course, rule out the possibility that democratic institutions have helped to produce
} 
still investigating the effects of these changed conditions on democratization and democratic durability, the underlying point here is that although neopatrimonial forms of rule may have persisted through regime changes, the environment in which African countries have been 'experimenting' with democratic institutions is considerably more favorable than it was in the 1970s and 1980s. Based on the experiences of patrimonial democracies outside of Africa (i.e. Italy or the U.S. in the 19th century), it seems reasonable to assume that democratic institutions, even if rooted in patrimonial authority, can indeed survive in such favorable conditions. This assumption becomes even more credible if we take seriously the perspectives of Pitcher et al. (2009), Mkandawire (2001), Médard (2000) and others that patrimonialism constitutes not only a mechanism of predation, but also a potential force for meaningful regulation and progress.

Our challenge then, is not solely to understand if neopatrimonial democratic rule reflects a lesser and more vulnerable form of democracy, though that is certainly important, but to better understand how configurations of formal democratic institutions interact with patrimonial authority to produce different regime outcomes. Building on the approach advanced by Lindberg (2006), the analysis below seeks to better understand the "partial regimes" that comprise neopatrimonial democracy in Africa, rather than seeking to conceptualize African democracy based on its neopatrimonial reputation. ${ }^{4}$ In the sections that follow, we investigate empirically the extent to which, and the ways in which, patrimonialism pervades formal political regimes which, as Young (2012) notes, are becoming increasingly more varied in Africa. We do so by constructing a multi-dimensional index of neopatrimonialism, comparing this index cross-regionally and cross-nationally, and assessing how, if at all, neopatrimonialism undermines advances in democracy.

\section{Measuring Neopatrimonialism}

Following Bratton and Van de Walle (1997) we define a neopatrimonial regime as one that includes clientelism, presidentialism and the use of public resources for private/political benefit. Clientelism reflects the targeted contingent exchange of goods and services for political support (Kitschelt and Wilkinson, 2007; Stokes et al., 2013). Presidentialism means the "systemic concentration of political power in the hands of one individual who resists delegating all but the most trivial decision making tasks" (1997, 63). The third dimension - state resources for political legitimation - captures the extent to which politicians treat

these improved conditions, there is evidence that autocratic countries often performed similarly during this time (Ross, 2006).

4The term "partial regime" is borrowed from Schmitter (1992). 
public office as a private resource (Bratton and Van de Walle, 1997, 66).

Following this conceptual outline, we use indicators from the V-Dem dataset to construct an index of neopatrimonial rule. ${ }^{5}$ The V-Dem dataset (Coppedge et al., 2017) includes measures of both de jure and de facto aspects of political regimes. The large selection of de facto indicators is particularly helpful for our purposes since, by definition, neopatrimonialism implies de facto practices guided by norms or informal rules that differ from those typically associated with the formal institutions in place. The V-Dem indicators (approximately 350 in total) are based on assessments by experts who are based both within and outside each country. The dataset is currently based on data submitted by almost 3,000 country experts and covers 176 countries, including all sub-Saharan African countries, from 1900 to $2016{ }^{6}$

We include indicators capturing three main dimensions of neopatrimonial rule: clientelism, presidentialism and regime corruption (which we equate to the private use of state resources). In addition to an overall index measuring the latent concept of neopatrimonial rule predicted by indicators across these three dimensions, we also produce sub-indices for each of the three dimensions. The sub-indices permit finer-grained analysis to better understand patterns of variation across the three dimensions and how the different dimensions relate to one another. A list of indicators used to construct the indices appears in Table 1.

All variables are scaled such that higher scores represent higher "neopatrimonial" values of the variable. ${ }^{7}$ In the Clientelism index we include an indicator of the frequency of votebuying in the last election, a measure of whether public spending tends to be more targeted (particularistic) or more encompassing, and an indicator measuring whether party-voter linkages tend to be more programmatic or more clientelistic. The Presidentialism index includes a number of indicators measuring the extent to which executive, legislative, judicial

\footnotetext{
${ }^{5}$ It's important to note that we focus on neopatrimonialism in political regimes, rather than in the state apparatus. While it is impossible to completely separate the two, we follow Mazzuca's (2010) approach of distinguishing between the institutions, processes and actions surrounding access to power (regime) and the exercise of power (the state). Of course, the two are related, especially in terms of state officials' actions designed to increase chances of retaining access to power, and we include such actions in our purview of the regime.

${ }^{6}$ For details on expert coders, their recruitment and management, see Coppedge et al. (2017b). VDem's approach to developing indicators of hard-to-measure concepts involves several safeguards that aim to ensure both validity and reliability. First, V-Dem employs coders with expertise in the particular country and substantive area (i.e. legislatures, executive, civil liberties) for which they are being asked to code. Second, for each country and indicator, V-Dem seeks at least five experts with diverse backgrounds, including those who were born in or currently live in that country. Third, V-Dem has developed a state-of-the-art measurement model to aggregate coder ratings from the five experts for each data point. The model uses a Bayesian ordinal item-response model providing a high degree of cross-country and cross-time comparability and estimates of uncertainty associated with each data point (Pemstein et al., 2017). Details of each indicator can be found in the V-Dem Version 7.1 Codebook (Coppedge et al., 2017a). See also, V-Dem Methodology (Coppedge et al., 2017b).

${ }^{7}$ Since V-Dem indicators are typically scaled such that higher values reflect 'more democratic' scores, we construct the indices with V-Dem indicators then reverse the point and confidence estimates.
} 


\section{Table 1: Descriptive Statistics for Constituent Indicators}

\begin{tabular}{lccccc} 
Indicator & Mean & SD & Min & Max & N \\
\hline Clientelism & & & & & \\
Vote Buying & 0.14 & 1.33 & -2.97 & 3.65 & 13,862 \\
Particularistic or Public Goods & 0.01 & 1.39 & -3.39 & 3.13 & 17,600 \\
Programmatic/Clientelistic Parties & -0.02 & 1.38 & -3.03 & 3.29 & 17,431 \\
\hline Presidentialism & & & & & \\
Executive Respects Constitution & 0.18 & 1.39 & -3.29 & 3.52 & 17,494 \\
Executive Oversight & -0.75 & 1.79 & -2.98 & 3.23 & 17,604 \\
Legislature Controls Resources & -0.50 & 1.58 & -2.31 & 2.33 & 17,604 \\
Legislature Investigates Executive & -0.75 & 1.83 & -3.00 & 3.68 & 17,604 \\
High Court Independence & 0.01 & 1.35 & -3.28 & 3.56 & 17,539 \\
Lower Court Independence & 0.18 & 1.40 & -3.49 & 3.61 & 17,539 \\
Compliance with High Court & 0.24 & 1.40 & -3.83 & 3.11 & 17,441 \\
Compliance with Judiciary & 0.17 & 1.38 & -3.42 & 3.11 & 17,441 \\
Electoral Management Body Autonomy & -0.20 & 1.62 & -2.84 & 3.89 & 17,437 \\
\hline Regime Corruption & & & & & \\
Executive Embezzlement & 0.25 & 1.47 & -3.02 & 3.44 & 17,494 \\
Executive Bribes & 0.19 & 1.47 & -3.15 & 3.73 & 17,497 \\
Legislative Corruption & 0.16 & 1.34 & -3.23 & 3.42 & 14,998 \\
Judicial Corruption & 0.42 & 1.35 & -3.14 & 3.28 & 17,524 \\
\hline
\end{tabular}

and electoral management bodies are, de facto, autonomous from the chief executive, and to what extent these institutions constrain the power of the executive. The Regime Corruption index includes indicators measuring the extent of executive embezzlement, executive bribery, legislative corruption and judicial corruption. We specifically exclude V-Dem's measures of public sector corruption since, in many cases, public sector workers may not be directly linked to those elected or appointed to office.

Each of the four indices are derived using a Bayesian factor analysis (BFA) implemented using MCMCpack in R (Martin et al., 2017). ${ }^{8}$ One distinct advantage of this method is that it produces confidence intervals for each estimate, taking rater accountability and uncertainty of the MCMC analysis into account. The BFAs estimate the latent concepts from the means of the posterior distributions of each of the V-Dem indicators included in each dimension. The overall Neopatrimonial index uses the BFA technique on the pool of 16 indicators employed in the three sub-indices. The BFA results for the global sample are presented in Table 2.

\footnotetext{
${ }^{8}$ The specific techniques used are described in Coppedge et al. (2017b).
} 
Table 2: Neopatrimonial Indices Summary Statistics (All Countries, 1900-2016)

\begin{tabular}{lccccc} 
Index & Mean & St. Dev. & Min & Max & N \\
\hline Clientelism & -0.17 & 0.89 & -2.42 & 2.25 & 13838 \\
Presidentialism & 0.37 & 0.97 & -1.93 & 2.30 & 17274 \\
Regime Corruption & 0.00 & 0.97 & -2.26 & 2.18 & 14953 \\
Neopatrimonialism & 0.07 & 0.98 & -2.24 & 2.31 & 13724
\end{tabular}

\section{How Neopatrimonial are African Regimes?}

With these four measures, we can assess the extent to which African regimes live up to their neopatrimonial reputations. We do so first by comparing trends in the four indices across regions of the world, then by examining variation across African countries, and finally across regime types.

\subsection{Regional Trends}

Figure 1 shows post-WWII trends in the Neopatrimonial Regime index across regions. ${ }^{9}$ Several patterns stand out. First, except for Western Europe/North America, most regions remain just around .5 for much of their post-War history. The non-Western regions begin to diverge a bit more in the late 1980s and early 1990s, at which point Eastern Europe/Central Asia, Latin America and East Asia break away from the other regions and become slightly less neopatrimonial. For much of the 1990s and 2000s, scores for African regimes were indistinguishable from those of the Middle East/North Africa, Southeast Asia and South Asia. In recent years South-East Asia's scores have decreased, though their confidence intervals (not depicted in the graph) still overlap with those of Africa's. In short, the continent seems much less "exceptionally neopatrimonial" than much of the literature on African politics has usually assumed.

Turning to regional trends for each of the sub-indices, it becomes clear that the differences between Africa and other regions are, in general, not driven by major differences in levels of clientelism. In Figure 2 we see that all regions outside of the West again tend to cluster, this time just above the mean. Eastern Europe/Central Asia becomes more clientelistic (lower scores on the Clientelism index) since the fall of the Soviet Union, while East Asia is the only non-Western region to show significant improvement over time. Yet, it is also true that Africa may be the most clientelistic in the current period, though the confidence intervals

\footnotetext{
${ }^{9}$ For figures 1 - figures 4 we show point estimates over time for each region along with confidence intervals for sub-Saharan Africa. For readability purposes, we do not include confidence intervals for other regions.
} 
Figure 1: Global Trends in Neopatrimonialism Index

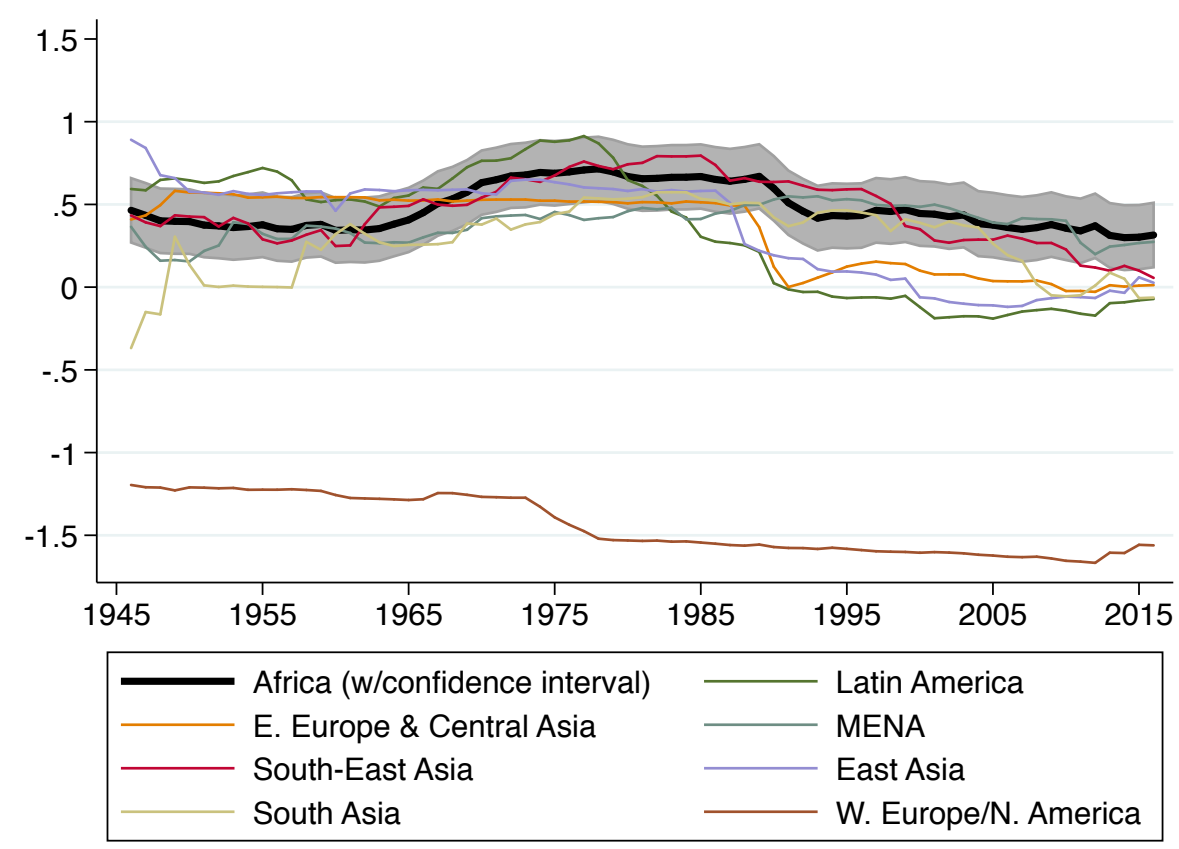

suggest some murkiness in that regard.

With respect to the Presidentialism index (Figure 3), two patterns stand out. First, Africa is not significantly more or less 'presidentialistic' than many other non-Western regions. Again, this goes against much of the received wisdom in African politics. Developments follow somewhat predictable trajectories: decreasing levels of presidentialism around the time of independence in the early 1960s when many countries were holding elections and adopting democratic forms of rule. Another period of decreasing levels of presidentialism in Africa comes at the outset of the 'Third Wave' in the early 1990s with a trend downwards since then. Additionally, levels of Presidentialism fluctuate over time to a somewhat greater extent than the other indices. This fluctuation suggests that factors other than neopatrimonialism may be at play, something we explore in greater detail below.

Finally, in Figure 4 we see a relatively consistent upward trend in the Regime Corruption index for Africa, with slight improvements in the last several years. On this dimension, Africa seems to stand out more in comparison with the rest of the world. With the exception of Eastern Europe/Central Asia, other regions tend to improve on this index, especially East Asia and Latin America since the early 1990s. Slight increases since 2010 across the remaining regions (including Africa) suggest, perhaps, the existence of some global trend that coincides with the launch of anti-corruption campaigns in many countries.

These graphs indicate several important realities about the global trajectories of neopat- 
Figure 2: Global Trends in Clientelism Index

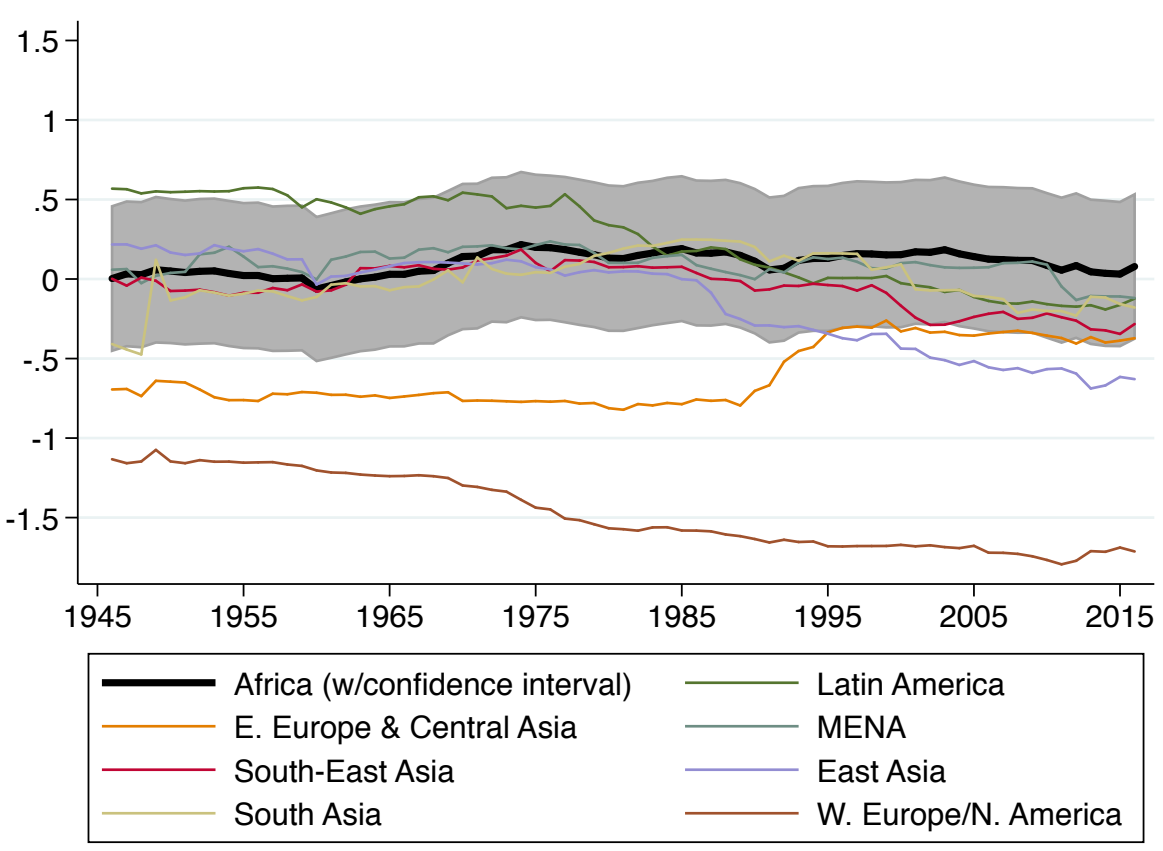

Figure 3: Global Trends in Presidentialism Index

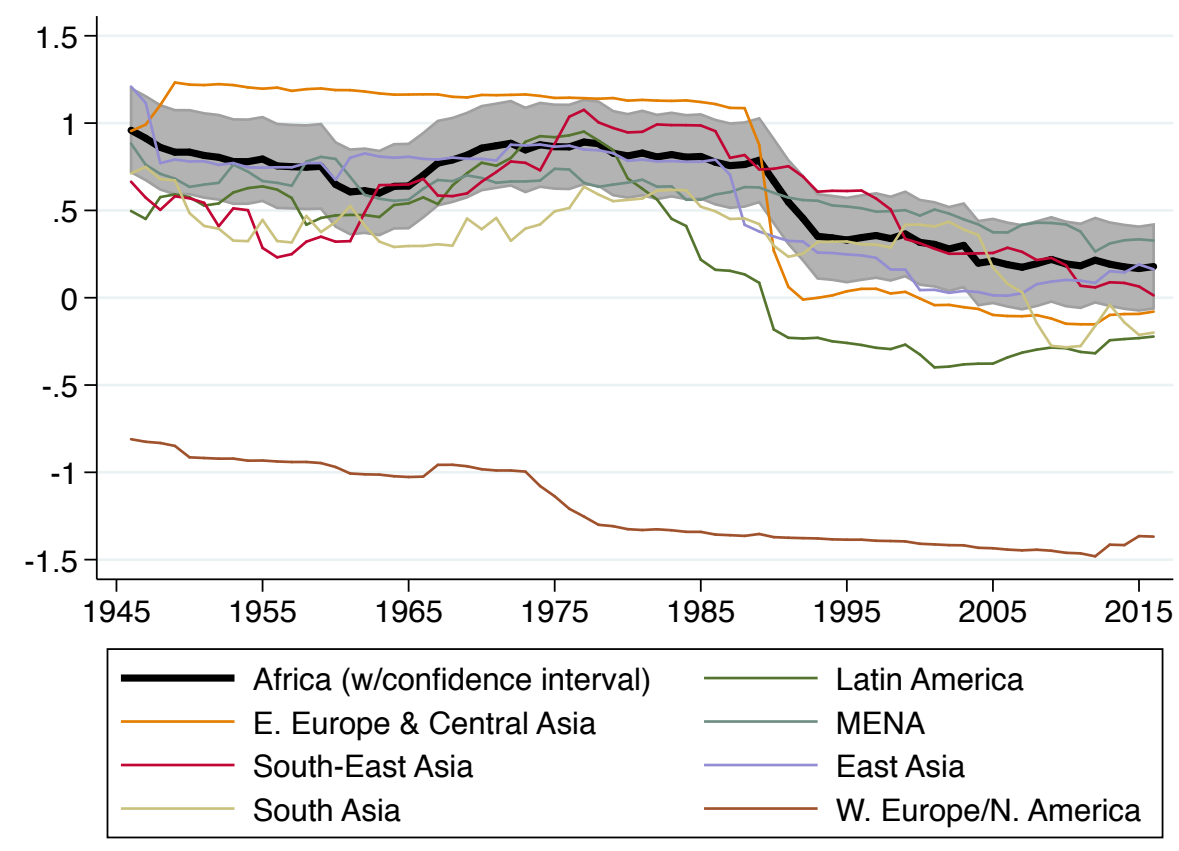


Figure 4: Global Trends in Regime Corruption Index

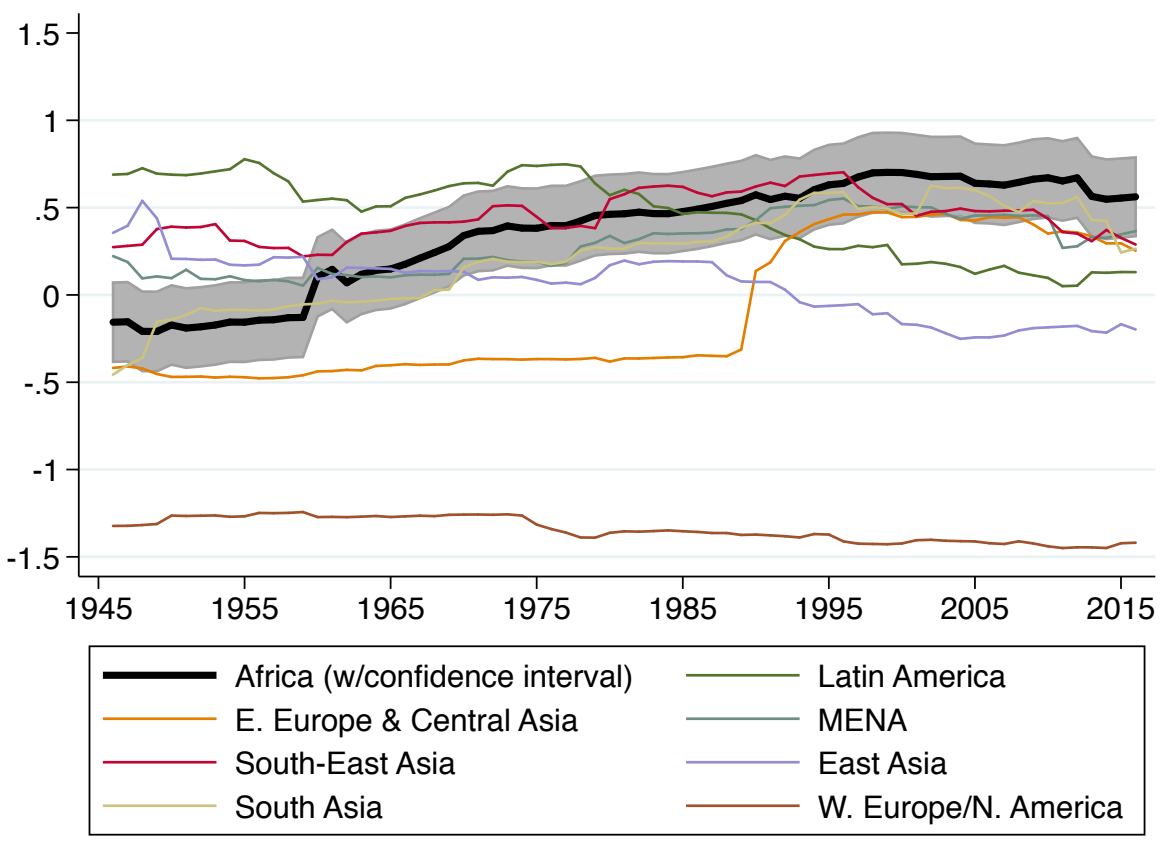

rimonial rule. First, contrary to widespread assumption, for much of the post-War period Africa has not varied significantly from other regions of the world on any of the three dimensions, or in the overall Neopatrimonial index. Where divergence among non-Western regions is evident, it appears in most cases to be a relatively recent phenomenon. Second, African regimes today are not, for the most part, significantly more presidentialistic than those in most other non-Western regions. Third, neopatrimonialism in Africa has remained relatively constant, with slight improvements in some areas, since the wave of democratization and regime transitions of the 1990s and early 2000s. Taken together, these observations challenge the more pessimistic views that tend to accompany discussions of neopatrimonial rule in Africa, or assume that Africa is both unique and extreme in its extent of neopatrimonialism.

\subsection{Variation Across African Countries}

We next explore the extent to which neopatrimonialism varies across African countries. Figure 5 shows estimates and confidence intervals for the Neopatrimonial index for African countries in 2015. Clear differences are visible not only between those with the highest scores (Chad and Eritrea) and those with the lowest scores (Cape Verde, South Africa and Botswana), but also between those hovering around the 75 th percentile (i.e. Angola and 
Figure 5: Neopatrimonialism Index 2015 Scores

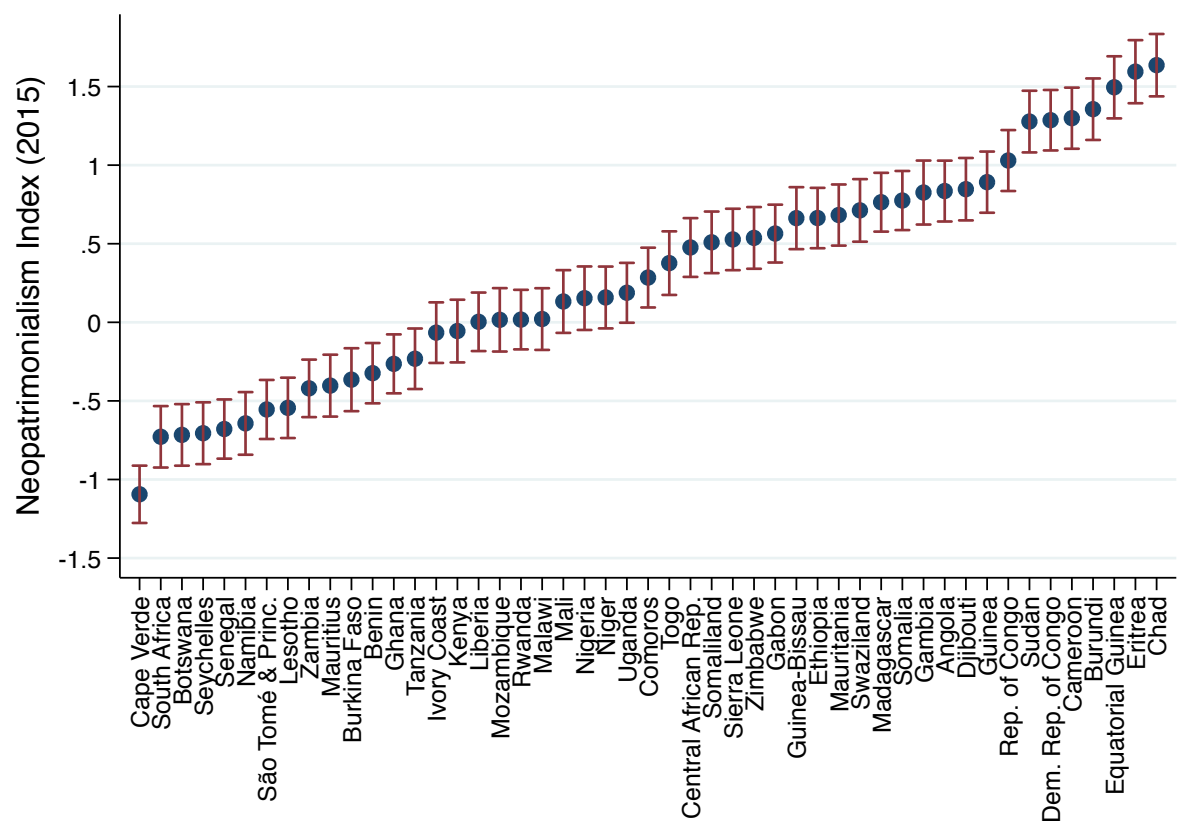

Madagascar) and those around the 25th percentile (i.e. Tanzania and Ghana).

We further explore patterns underlying the neopatrimonialism index in African countries by plotting country scores on the three sub-indices. Figure 6 plots countries according to their 2015 scores on the Clientelism and Presidentialism indices. While there is a clear positive correlation, we see quite a few countries falling far from the best-fit line. The variance is especially high with countries above the best-fit line where we see a number of countries scoring relatively low on the Clientelism index yet higher or average on the Presidentialism index. Rwanda and Ethiopia, among others, stand out in this regard. These regimes combine high levels of presidentialism with low levels of clientelism. Developmental policies in Rwanda and Ethiopia, for example, whereby governments provide an array of public goods and services, perhaps in lieu of particularistic ones, suggest that high levels of presidentialism may not always couple with the types of patronage we tend to associate with neopatrimonial regimes. On the other end of the spectrum, well below the best-fit line, are countries like Benin and Ghana whose levels of presidentialism are relatively low but whose scores on the Clientelism index suggest high levels of vote buying, particularistic goods distribution and clientelistic party linkages. These two sets of deviant cases may provide important clues about when and why clientelism and presidentialism are not necessarily associated with each other in ways in that theories of neopatrimonial rule tend to predict.

The positive relationship between the Clientelism index and the Regime Corruption index 
Figure 6: Clientelism and Presidentialism 2015

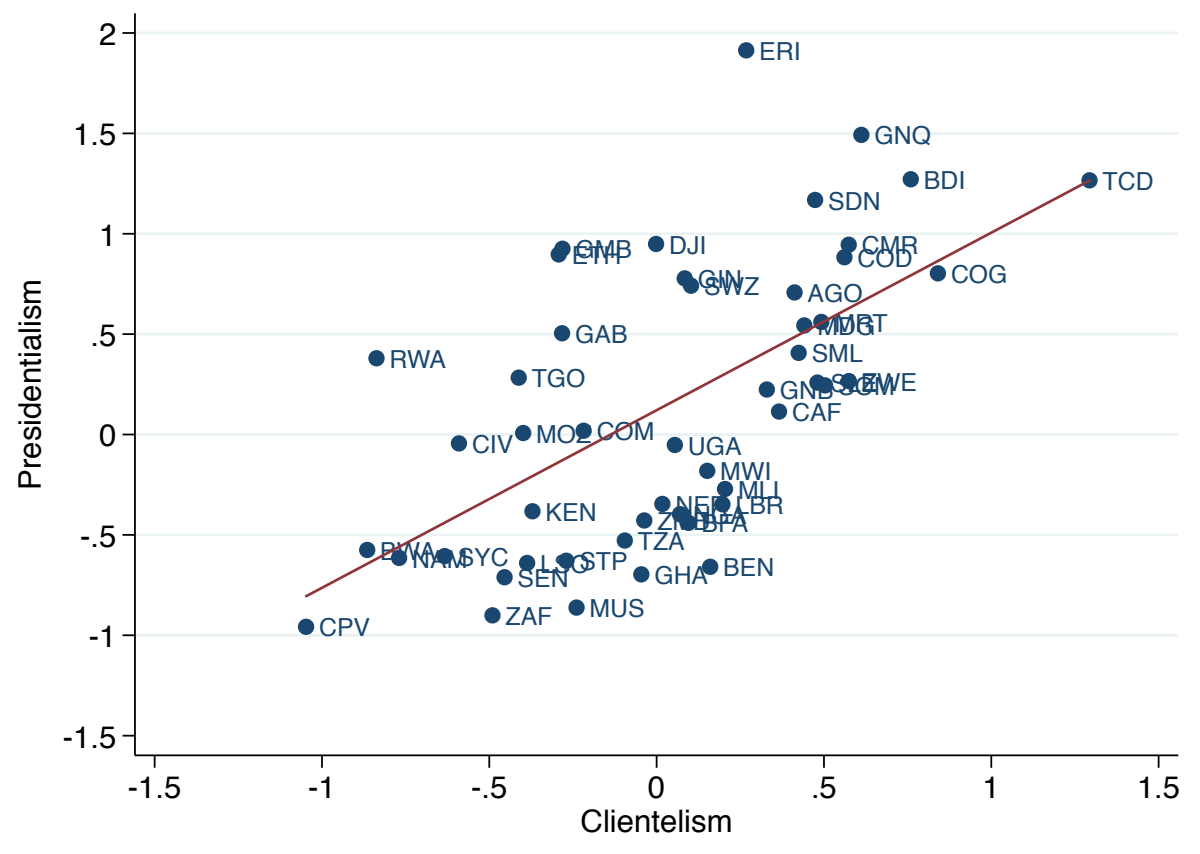

is stronger, as shown in 7, but with some important exceptions. Those countries with higher levels of clientelism tend to cluster at lower levels on the Regime Corruption scale, signifying higher overall levels of corruption. Included in this group are Chad, Democratic Republic of Congo, Burundi and others. There are a number of deviant cases, however, clustered at middling levels of clientelism and relatively high levels of corruption including, for example, Burkina Faso, Zambia and Senegal. These countries, while practicing high levels of political patronage, appear to have prebendal-types of arrangements in greater check than do many other countries where clientelism and corruption may mutually reinforce each other.

If we look for Burkina Faso, Zambia and Senegal in Figure 8, which plots the Regime Corruption and Presidentialism indices, we see that all three countries are clustered at the bottom left, meaning low levels of both regime corruption and presidentialism. ${ }^{10}$ We thus have at least a small cluster of countries with higher-than-average levels of clientelism, relatively low levels of presidentialism and relatively low levels on the Regime Corruption index. Another larger clustering, composed of Ghana, Benin, Tanzania, Nigeria among others, display lower-than-average levels of presidentialism with middling levels of corruption and relatively high levels of clientelism. These different clusterings suggest that relationships between the three dimensions are likely to be conditional on other factors, and that we do

\footnotetext{
${ }^{10}$ Note that this is after the fall of President Blaise Compaore's regime in Burkina Faso, which had rated considerably higher on the Presidentialism index.
} 
Figure 7: Clientelism and Regime Corruption 2015

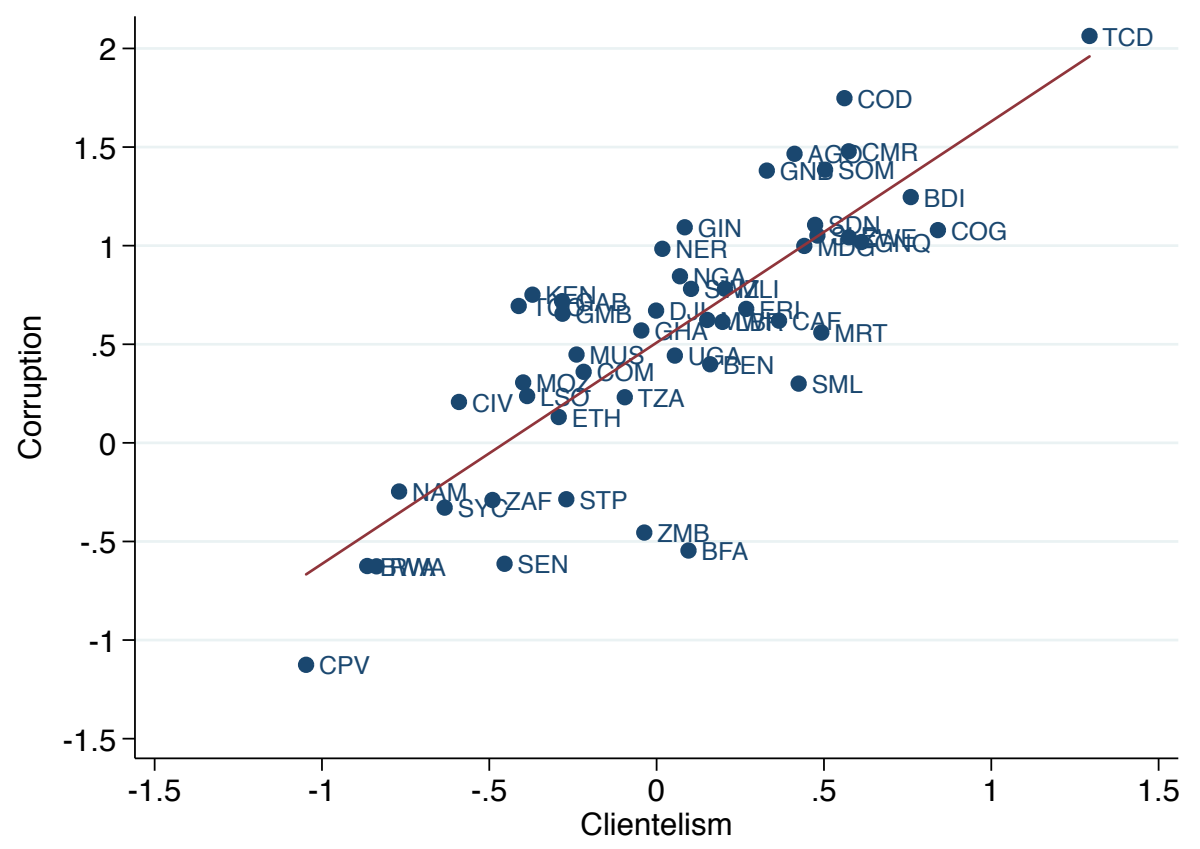

not see all dimensions of neopatrimonial rule developing in tandem.

We conclude from this section that African regimes demonstrate important variation both qualitative and quantitative - in their embodiment of neopatrimonial rule. While there exists a strong relationship between clientelism and regime corruption, there are nonetheless some important instances in which politicians are elected using programmatic forms of mobilization, yet use their offices for private benefit, or vice versa. Deviant cases, such as Burkina Faso and Zambia, may help to provide clues as to when and why these two facets of neopatrimonial rule do not coincide.

The differentiation between presidentialism on the one hand and clientelism or corruption, on the other hand, is considerably more clear and theoretically important for understanding the relationship between neopatrimonialism and democracy. While a cluster of countries combines lower levels of presidentialism with lower levels of clientelism, we find that countries with relatively low levels of presidentialism may vary considerably in the extent to which their politics are clientelistic and their elected officials engage in the private use of public office. That presidentialism does not map easily onto the other dimensions suggests an uneasy relationship between regime type, executive power and neopatrimonialism. We examine this relationship more concretely in the next section. 
Figure 8: Presidentialism and Regime Corruption 2015

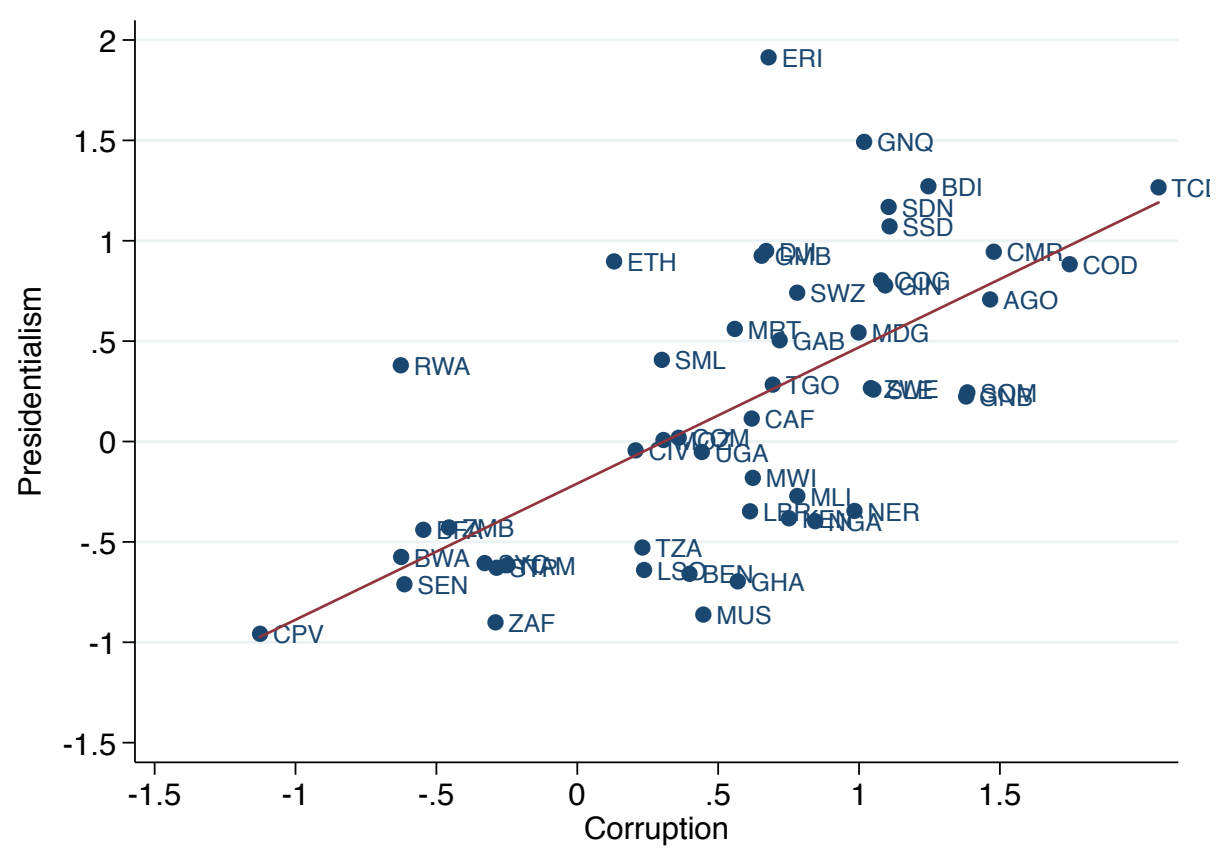

\subsection{Neopatrimonialism Across Regime Types}

As described above, pessimism about democracy in Africa is often driven by the notion of continuity in neopatrimonial rule despite changes in formal regime institutions. We investigate this idea of neopatrimonial continuity by simply comparing average scores across different regime types across Africa from 1960-2016, as seen in Figure 9. ${ }^{11}$

It is clear from Figure 9 that closed autocracies are, on the whole, most neopatrimonial while liberal democracies are least so. The three sub-indices, however, differ considerably in the extent to which they vary across the different regime types. Most notably, average scores on the Presidentialism index have the largest difference between autocratic and democratic regime types, with a clear linear relationship from the most "presidentialistic" in closed autocracies, to the least in liberal democracies. While this is not surprising given the close association between autocracy and unconstrained rulers, it also suggests that concerns about democracies in Africa remaining highly presidentialistic may be overstated. The graphs also illustrate that average scores on the Clientelism index are considerably lower in liberal democracies than in electoral democracies, while scores on the Regime Corruption index remain relatively high (hovering around 0) in liberal democracies. Together, these

\footnotetext{
${ }^{11}$ We use a measure of regime type, called Regimes in the World (RIW), developed by Lührmann et al (Lührmann et al.) using V-Dem data. It classifies all regimes into the four categories appearing in Figure 9. The graphs look very similar if we restrict the time span only to more recent years.
} 
Figure 9: Neopatrimonialism and Regime Types in Africa, 1960-2016

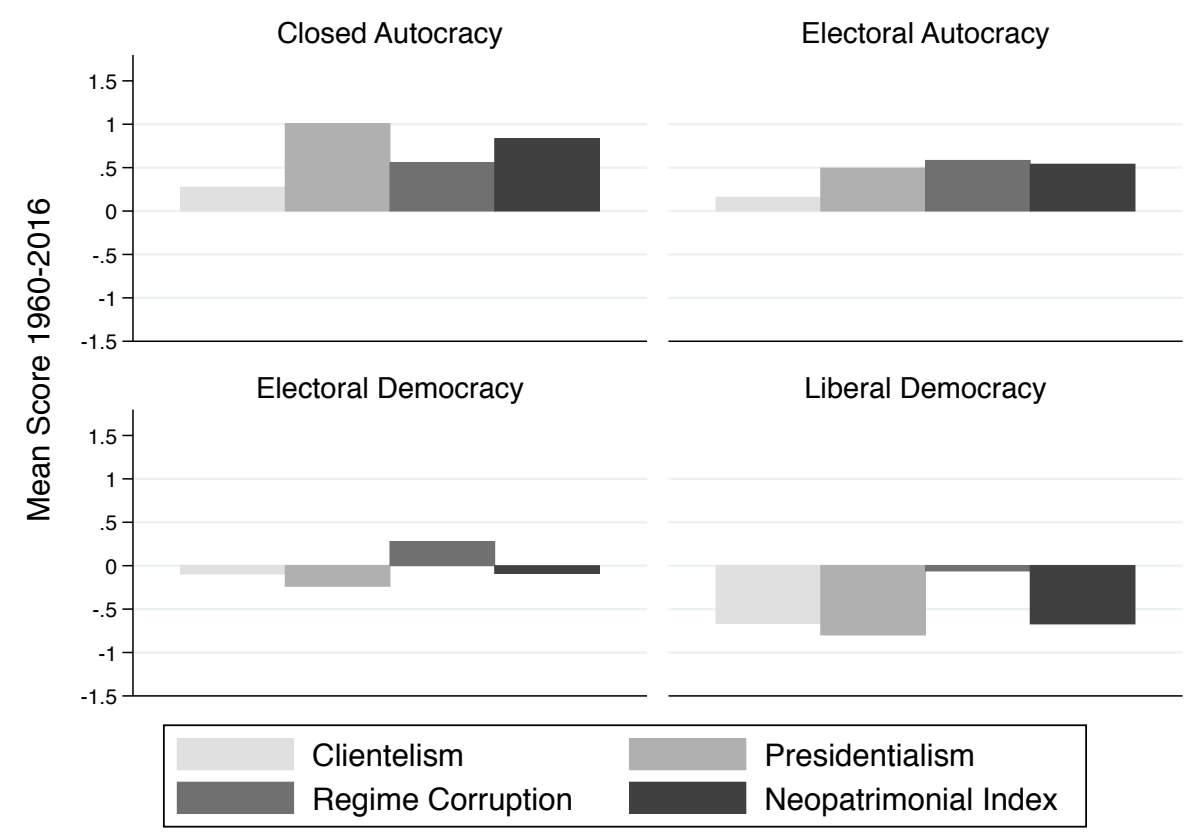

observations suggest that while democratization may not fundamentally change behavior regarding the private use of public office, it does appear to have some kind of relationship to decreasing levels of both clientelism and presidentialism.

\section{Does Neopatrimonialism Constrain Democracy?}

Finally, we use the indices to investigate whether and how neopatrimonialism may act as an impediment to democracy in Africa. To do so, we present results for models estimating the effects of neopatrimonialism on democratic survival and advancement. We find that presidentialism, perhaps unsurprisingly given its close definitional relationship to democracy itself, does indeed limit the survival and advancement of democracy. By contrast, however, clientelism and regime corruption have, at best, ambiguous effects on democracy.

We first estimate the effects of neopatrimonialism on the probability that a democratic regime in Africa, once in place, survives for 5 subsequent years. ${ }^{12}$ We estimate two sets of dynamic probit models, one with random effects and a battery of control variables, the other with country fixed-effects and no control variables. ${ }^{13}$ To avoid using V-Dem data in both

\footnotetext{
${ }^{12}$ This is a common approach to measuring and estimating democratic survival. For a recent example, see Graham et al. (2017).

${ }^{13}$ Combining fixed effects and time-varying control variables decreases the number of observations such
} 
our independent and dependent variables, we use an updated version of Boix, Miller and Rosato's (2012) dichotomous coding of regime type to measure survival. Table 3 shows the results. In models 1 and 4, we see that the high levels of neopatrimonialism as measured by the Neopatrimonial index have a very strong, statistically significant negative effect on the probability of 5-year democratic survival. When we break down the Neopatrimonial index into its constitutent dimensions, as seen in models 2, 3, 5 and 6, however, it becomes clear that presidentialism is largely driving these results. Neither clientelism nor regime corruption have consistent effects on democratic survival. This finding runs contrary to concerns expressed in much of the literature on African politics that clientelism, corruption and presidentialism interact to undermine democracy. ${ }^{14}$

We next examine whether neopatrimonialism limits positive changes in the level of democracy. In this set of tests, we use time-series cross-sectional OLS regression with fixed effects to measure the effects of neopatrimonialism in time $t$ on 5 -year subsequent changes in Polity2 scores. ${ }^{15}$ Again, as seen in Table 4 only presidentialism has a statistically significant effect on the change in Polity2 score. However, this relationship between presidentialism appears contingent on the level of democracy as reflected in the coefficients displayed Model 5, where presidentialism loses its statistically significant effect when the interaction term is included in the model. We explore this potential contingency in more detail below.

Given the strong effects of Polity2 scores on subsequent democratic change across these models, we repeat the analysis dividing the sample between countries classified as democratic by the V-Dem RIW measure in time $t$ and those classified as non-democratic. Figures 10 and 11 display the predicted values resulting from this divided sample analysis, which is specified in the same way as Model 5 above (the model with the highest within-country R-squared value). Each figure plots the predicted change in Polity2 at different levels of the Presidentialism index for the post-Cold War years, 1990-2015.

There is strong evidence of discontinuity across the two models. In democratic countries, higher levels of presidentialism are, as expected, associated with negative change in Polity2 score, though there is a high degree of variance in predicted changes. In non-democratic countries (V-Dem RIW classification as closed or electoral autocracy), countries with high

that it becomes difficult to have confidence in the results. Control variables include, first, from World Bank (2017): Log per capita GDP, GDP Growth, Log per capita official development assistance (ODA). We include a measure of fuel dependence used by Graham et al. (2017), as well as their measure of the age of democracy calculated from the BMR dichotomous regime measure. We also include Hanson and Sigman's (2013) measure of state capacity, Ethno-linguistic fractionalization from Alesina et al. (2003) and a dummy variable for post-Cold War years.

${ }^{14}$ The findings are similar for 2-year and 8-year survival rates. Due to space limitations, we do not present those results.

${ }^{15}$ The results presented in Table 4 are consistent in random effects models as well. 
Table 3: Effects of Neopatrimonialism on Democratic Survival

\begin{tabular}{|c|c|c|c|c|c|c|}
\hline Neopatrimonialism & $\begin{array}{c}(1) \\
-4.788^{* * *} \\
(-3.94)\end{array}$ & 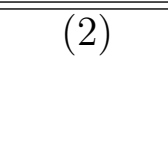 & 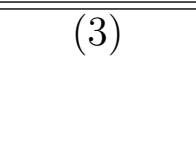 & $\begin{array}{c}(4) \\
-1.604^{* * *} \\
(-4.10)\end{array}$ & 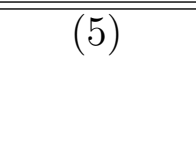 & 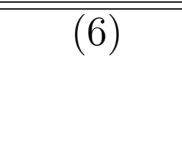 \\
\hline Clientelism & & $\begin{array}{l}-1.797 \\
(-1.86)\end{array}$ & & & $\begin{array}{l}0.132 \\
(0.24)\end{array}$ & \\
\hline Presidentialism & & $\begin{array}{c}-2.067^{* *} \\
(-3.03)\end{array}$ & $\begin{array}{c}-2.277^{* * *} \\
(-3.33)\end{array}$ & & $\begin{array}{c}-1.443^{* * *} \\
(-3.33)\end{array}$ & $\begin{array}{c}-0.887^{* *} \\
(-2.66)\end{array}$ \\
\hline Regime Corruption & & & $\begin{array}{l}-0.587 \\
(-0.79)\end{array}$ & & & $\begin{array}{c}-1.153^{* *} \\
(-3.27)\end{array}$ \\
\hline Log Per Capita GDP & & & & $\begin{array}{c}1.050^{* *} \\
(2.59)\end{array}$ & $\begin{array}{l}0.555 \\
(1.57)\end{array}$ & $\begin{array}{c}1.209^{* *} \\
(2.70)\end{array}$ \\
\hline Oil Dependence & & & & $\begin{array}{l}-0.023 \\
(-1.84)\end{array}$ & $\begin{array}{l}0.021 \\
(0.74)\end{array}$ & $\begin{array}{c}-0.031^{*} \\
(-2.04)\end{array}$ \\
\hline GDP Growth & & & & $\begin{array}{l}-0.025 \\
(-1.21)\end{array}$ & $\begin{array}{c}0.070^{*} \\
(2.04)\end{array}$ & $\begin{array}{l}-0.021 \\
(-0.98)\end{array}$ \\
\hline Log Per Capita ODA & & & & $\begin{array}{l}-0.087 \\
(-0.46)\end{array}$ & $\begin{array}{l}0.125 \\
(0.50)\end{array}$ & $\begin{array}{l}-0.184 \\
(-0.88)\end{array}$ \\
\hline $\mathrm{ELF}$ & & & & $\begin{array}{c}-3.274^{* *} \\
(-2.95)\end{array}$ & $\begin{array}{l}-0.145 \\
(-0.18)\end{array}$ & $\begin{array}{c}-3.345^{* *} \\
(-3.07)\end{array}$ \\
\hline Democracy Age & & & & $\begin{array}{c}-0.092^{* * *} \\
(-3.57)\end{array}$ & $\begin{array}{c}0.028^{*} \\
(2.25)\end{array}$ & $\begin{array}{c}-0.091^{* * *} \\
(-3.44)\end{array}$ \\
\hline Capacity & & & & $\begin{array}{l}-0.230 \\
(-0.52)\end{array}$ & $\begin{array}{l}-0.575 \\
(-1.41)\end{array}$ & $\begin{array}{l}-0.366 \\
(-0.78)\end{array}$ \\
\hline Post-Cold War & & & & $\begin{array}{c}1.441^{* * *} \\
(3.67)\end{array}$ & $\begin{array}{l}0.757 \\
(1.76)\end{array}$ & $\begin{array}{c}1.674^{* * *} \\
(3.64)\end{array}$ \\
\hline Constant & $\begin{array}{l}-0.588 \\
(-1.11)\end{array}$ & $\begin{array}{l}-0.977 \\
(-1.57)\end{array}$ & $\begin{array}{l}-0.499 \\
(-0.62)\end{array}$ & $\begin{array}{l}-3.656 \\
(-0.88)\end{array}$ & $\begin{array}{l}-5.973 \\
(-1.29)\end{array}$ & $\begin{array}{l}-3.499 \\
(-0.81)\end{array}$ \\
\hline $\mathrm{N}$ & 142 & 142 & 142 & 301 & 285 & 301 \\
\hline N (Countries) & 28 & 28 & 28 & 28 & 28 & 28 \\
\hline Pseudo R-Sq & 0.219 & 0.203 & 0.188 & 0.416 & 0.260 & 0.430 \\
\hline Country-Fixed Effects & Yes & Yes & Yes & No & No & No \\
\hline
\end{tabular}
Probit model estimating probability of democratic survival after five years. Z-statistics in parentheses. ${ }^{*} p<.05{ }^{* *} p<.01{ }^{* * *} p<.01$ 


\section{Table 4: Effects of Neopatrimonialism on Democratic Improvement}

\begin{tabular}{|c|c|c|c|c|c|c|}
\hline & (1) & (2) & (3) & (4) & (5) & (6) \\
\hline Neopatrimonialism & $\begin{array}{l}-0.739 \\
(-1.26)\end{array}$ & & & $\begin{array}{l}-1.728 \\
(-1.98)\end{array}$ & & \\
\hline Polity2 & $\begin{array}{c}-0.348^{* * *} \\
(-8.51)\end{array}$ & $\begin{array}{c}-0.455^{* * *} \\
(-7.54)\end{array}$ & $\begin{array}{c}-0.483^{* * *} \\
(-7.23)\end{array}$ & $\begin{array}{c}-0.533^{* * *} \\
(-7.20)\end{array}$ & $\begin{array}{c}-0.597^{* * *} \\
(-8.88)\end{array}$ & $\begin{array}{c}-0.590^{* * *} \\
(-8.54)\end{array}$ \\
\hline Neopatrimonialism*Polity2 & $\begin{array}{l}-0.052 \\
(-0.77)\end{array}$ & & & $\begin{array}{c}-0.198^{*} \\
(-2.36)\end{array}$ & & \\
\hline Clientelism & & $\begin{array}{l}0.576 \\
(0.86)\end{array}$ & & & $\begin{array}{l}-0.128 \\
(-0.18)\end{array}$ & \\
\hline Presidentialism & & $\begin{array}{c}-1.780^{* *} \\
(-3.48)\end{array}$ & $\begin{array}{c}-2.104^{* * *} \\
(-3.87)\end{array}$ & & $\begin{array}{l}-1.130 \\
(-1.62)\end{array}$ & $\begin{array}{l}-1.119 \\
(-1.71)\end{array}$ \\
\hline Presidentialism*Polity2 & & $\begin{array}{l}-0.013 \\
(-0.22)\end{array}$ & $\begin{array}{l}-0.027 \\
(-0.43)\end{array}$ & & $\begin{array}{c}-0.160^{*} \\
(-2.14)\end{array}$ & $\begin{array}{l}-0.152 \\
(-2.01)\end{array}$ \\
\hline Regime Corruption & & & $\begin{array}{c}1.757^{* * * *} \\
(3.92)\end{array}$ & & & $\begin{array}{l}0.038 \\
(0.06)\end{array}$ \\
\hline Log Per Capita GDP & & & & $\begin{array}{c}-1.090^{*} \\
(-2.07)\end{array}$ & $\begin{array}{l}-0.990 \\
(-1.95)\end{array}$ & $\begin{array}{l}-0.895 \\
(-1.74)\end{array}$ \\
\hline Oil Dependence & & & & $\begin{array}{l}0.007 \\
(0.45)\end{array}$ & $\begin{array}{l}0.004 \\
(0.26)\end{array}$ & $\begin{array}{l}0.002 \\
(0.11)\end{array}$ \\
\hline GDP Growth & & & & $\begin{array}{l}-0.007 \\
(-0.87)\end{array}$ & $\begin{array}{l}-0.007 \\
(-0.89)\end{array}$ & $\begin{array}{l}-0.006 \\
(-0.81)\end{array}$ \\
\hline Democracy Age & & & & $\begin{array}{c}0.037^{*} \\
(2.03)\end{array}$ & $\begin{array}{l}0.036 \\
(1.92)\end{array}$ & $\begin{array}{l}0.035 \\
(1.88)\end{array}$ \\
\hline Capacity & & & & $\begin{array}{l}-0.142 \\
(-0.31)\end{array}$ & $\begin{array}{l}-0.125 \\
(-0.28)\end{array}$ & $\begin{array}{l}-0.170 \\
(-0.38)\end{array}$ \\
\hline Post-Cold War & & & & $\begin{array}{c}3.263^{* * *} \\
(4.56)\end{array}$ & $\begin{array}{c}3.153^{* * *} \\
(3.89)\end{array}$ & $\begin{array}{c}3.219^{* * *} \\
(4.06)\end{array}$ \\
\hline Constant & $\begin{array}{l}0.414 \\
(1.50) \\
\end{array}$ & $\begin{array}{l}0.096 \\
(0.26) \\
\end{array}$ & $\begin{array}{r}-0.984^{*} \\
(-2.05) \\
\end{array}$ & $\begin{array}{l}5.288 \\
(1.30) \\
\end{array}$ & $\begin{array}{l}4.029 \\
(1.03)\end{array}$ & $\begin{array}{l}3.237 \\
(0.80) \\
\end{array}$ \\
\hline $\mathrm{N}$ & 1762 & 1762 & 1788 & 1633 & 1633 & 1656 \\
\hline N Countries & 46 & 46 & 46 & 44 & 44 & 44 \\
\hline Within-Country R-Sq & 164 & 179 & 189 & .338 & .332 & .326 \\
\hline Fixed Effects & Yes & Yes & Yes & Yes & Yes & Yes \\
\hline
\end{tabular}

Time-series cross-section OLS model with fixed effects and standard errors clustered by country.

Dependent variable is 5-year subsequent change in Polity2 score.

T-statistics in parentheses. ${ }^{*} p<.05{ }^{* *} p<.01{ }^{* * *} p<.01$ 
Figure 10: Predicted Change in Polity2 in Democratic Countries, 1990-2015

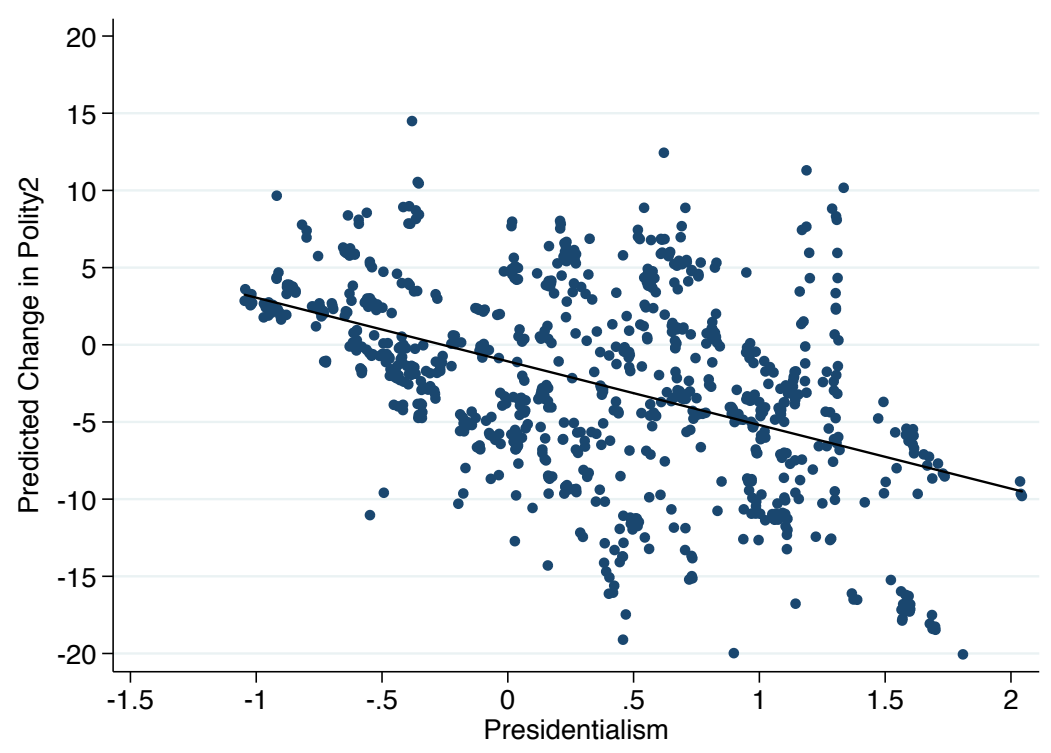

Figure 11: Predicted Change in Polity2 in non-Democratic Countries: 1990-2015

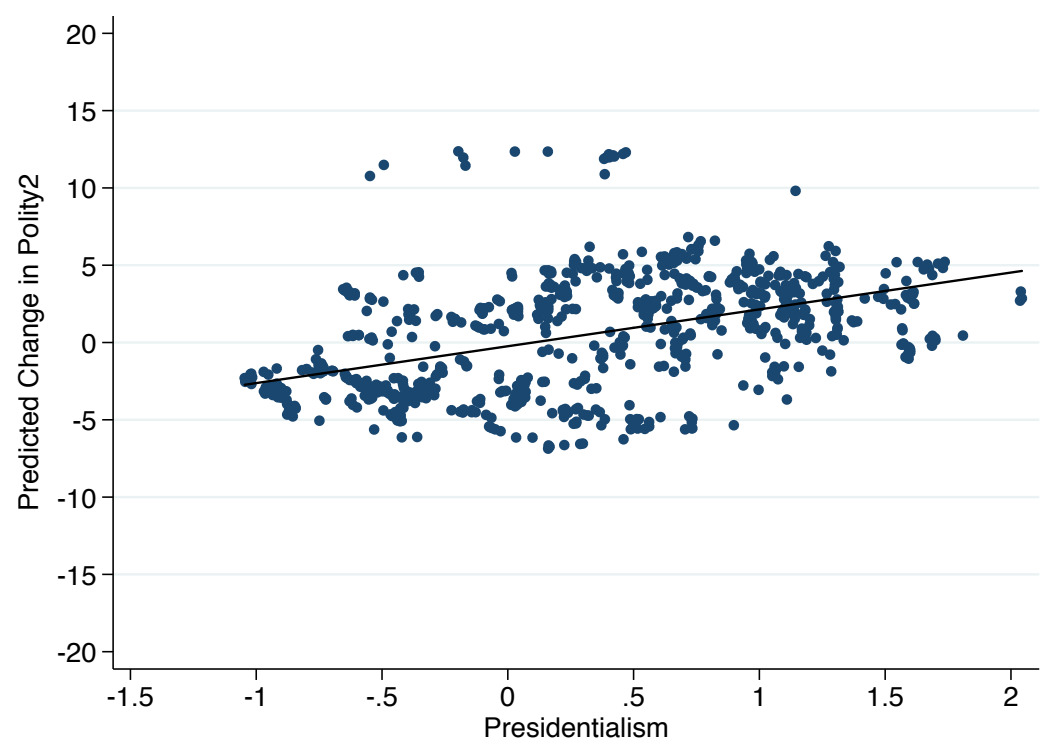


levels of presidentialism are more likely to experience positive changes in the Polity2 score over the subsequent five years, while those that are less presidentialistic are more likely to become less democratic. In sum, these results suggest that the impact of presidentialism on democracy is somewhat ambiguous in non-democratic contexts and negative, but inconsistent, in democratic ones.

\section{Conclusion}

Two features of political regimes in Africa - the prevalence of electoral authoritarianism and more democratic regimes with strong presidents - have fueled a large body of literature theorizing the links between patrimonial forms of authority and contemporary (undemocratic) regime outcomes throughout the continent. One consequence of this theory is that the concept of neopatrimonial democracy has become virtually synonymous with that of African democracy. The preceding analysis casts doubt on the strength of this association, as well as its alleged unique relevance to Africa.

In constructing and analyzing comprehensive measures of neopatrimonialism in African politcal regimes, we make three important observations. First, for much of the period since independence, African regimes have not been significantly more or less neopatrimonial than regimes in other parts of the developing world. Second, regimes in Africa vary considerably in the extent to which they embody various dimensions of neopatrimonialism. In particular, presidentialistic regimes may be present irregardless of the other facets of neopatrimonialism. Third, neopatrimonialism does not appear to act as a major hindrance to democratization and democratic survival in Africa. At best, its effects are likely to be contingent on a host of other regime factors.

More fundamentally, this exercise has highlighted the importance of disaggregating the concept of neopatrimonial rule. Doing so not only permits an investigation into the ways that particular dimensions may interact with each other, but is also bound to provide more nuanced theories about the ways that personalistic forms of authority permit or constrain the operation of democratic institutions. We look forward to colleagues and students picking up this challenge and making use of these new measures in substantive analyses in the years to come. 


\section{References}

Alence, R. (2004). Political Institutions and Developmental Governance in sub-Saharan Africa. The Journal of Modern African Studies 42(2), 163-187.

Alesina, A., A. Devleeschauwer, W. Easterly, S. Kurlat, and R. Wacziarg (2003). Fractionalization. Journal of Economic growth 8(2), 155-194.

Bach, D. C. (2011). Patrimonialism and Neopatrimonialism: Comparative Trajectories and Readings. Commonwealth $\&$ Comparative Politics 49(3), 275-294.

Barro, R. J. and J. W. Lee (2013). A New Data Set of Educational Attainment in the World, 1950-2010. Journal of Development Economics 104, 184-198.

Bayart, J.-F. (1993). The State in Africa: The Politics of the Belly (trans Mary Harper, Christopher Harrison \& Elizabeth Harrison).

Boix, C., M. Miller, and S. Rosato (2012). A complete data set of political regimes, 1800-2007. Comparative Political Studies, 0010414012463905.

Booth, D. and F. Golooba-Mutebi (2012). Developmental Patrimonialism? The Case of Rwanda. African Affairs 111(444), 379-403.

Bratton, M. and N. Van de Walle (1997). Democratic Experiments in Africa: Regime Transitions in Comparative perspective. Cambridge: Cambridge University Press.

Burgess, R., R. Jedwab, E. Miguel, A. Morjaria, et al. (2015). The Value of Democracy: Evidence from Road Building in Kenya. The American Economic Review 105(6), 1817-1851.

Chabal, P. and J. P. Daloz (1999). Africa Works: Disorder as Political Instrument.

Cheeseman, N. (2015). Democracy in Africa: Successes, failures, and the struggle for political reform, Volume 9. Cambridge University Press.

Clapham, C. S. (1985). Third World Politics: An Introduction. University of Wisconsin Press.

Collier, D. and S. Levitsky (1997). Democracy with adjectives: Conceptual innovation in comparative research. World politics 49(03), 430-451.

Coppedge, M., J. Gerring, S. I. Lindberg, S.-E. Skaaning, J. Teorell, D. Altman, M. Bernhard, M. S. Fish, A. Glynn, A. Hicken, C. H. Knutsen, A. Lürman, K. L. Marquardt, K. McMann, V. Mechkova, M. Olin, P. Paxton, D. Pemstein, J. Pernes, C. S. Petrarca, J. von Römer, L. Saxer, B. Seim, R. Sigman, J. Staton, N. Stepanova, and S. Wilson (2017). V-Dem [CountryYear/Country-Date] Dataset v7.1. Varieties of Democracy (V-Dem) Project. 
Coppedge, M., J. Gerring, S. I. Lindberg, S.-E. Skaaning, J. Teorell, J. Krusell, K. L. Marquardt, V. Mechkova, D. Pemstein, N. Stepanova, E. Tzelgov, Y. ting Wang, and S. Wilson (2017b). V-Dem Methodology (Version 7.1). Varieties of Democracy (V-Dem) Project.

Coppedge, M., J. Gerring, S. I. Lindberg, S.-E. Skaaning, J. T. with David Altman, M. Bernhard, M. S. Fish, A. Glynn, A. Hicken, C. H. Knutsen, K. McMann, V. Mechkova, P. Paxton, D. Pemstein, L. Saxer, B. Seim, R. Sigman, and J. Staton (2017a). V-Dem Codebook v7.1. Varieties of Democracy (V-Dem) Project.

Croese, S. (2017). State-led housing delivery as an instrument of developmental patrimonialism: the case of post-war Angola. African Affairs 116(462), 80-100.

Crook, R. C. (1989). Patrimonialism, Administrative Effectiveness and Economic Development in Côte d'Ivoire. African Affairs 88(351), 205-228.

Dunning, T. (2004). Conditioning the effects of aid: Cold War politics, donor credibility, and democracy in Africa. International Organization 58(2), 409-423.

Edgell, A. B., V. Mechkova, D. Altman, M. Bernhard, and S. I. Lindberg (2017). When and Where do Elections Matter? A Global Test of the Democratization by Elections Hypothesis, 1900-2010. Democratization, 1-23.

Eisenstadt, S. N. (1973). Traditional Patrimonialism and Modern Neopatrimonialism, Volume 1. Sage Publications (CA).

Erdmann, G. and U. Engel (2007). Neopatrimonialism Reconsidered: Critical Review and Elaboration of an Elusive Concept. Commonwealth $\&$ Comparative Politics 45(1), 95-119.

Graham, B. A., M. K. Miller, and K. W. StrØm (2017). Safeguarding Democracy: Powersharing and Democratic Survival. American Political Science Review, 1-19.

Hanson, J. K. and R. Sigman (2013). Leviathan's Latent Dimensions: Measuring State Capacity for Comparative Political Research.

Jackson, R. H. and C. G. Rosberg (1982). Personal Rule in Black Africa: Prince, Autocrat, Prophet, Tyrant. Berekeley: University of California Press.

Joseph, R. (2008). Challenges of a "frontier" region. Journal of Democracy 19(2), 94-108.

Joseph, R. A. (1987). Democracy and Prebendal Politics in Nigeria, Volume 56. Cambridge University Press.

Kelsall, T. (2013). Business, Politics, and the State in Africa: Challenging the Orthodoxies on Growth and Transformation. Zed Books Ltd. 
Kitschelt, H. and S. I. Wilkinson (2007). Patrons, Clients and Policies: Patterns of Democratic Accountability and Political Competition. Cambridge University Press.

Levitsky, S. and L. Way (2005). International Linkage and Democratization. Journal of Democracy $16(3), 20-34$.

Lindberg, S. I. (2006). Democracy and Elections in Africa. Baltimore: Johns Hopkins University Press.

Lührmann, A., S. I. Lindberg, and M. Tannenberg. Regimes In the World (RIW): A Robust Regime Type Measure based on V-Dem. V-Dem Working Paper No. 47.

Lynch, G. and G. Crawford (2011). Democratization in Africa 1990-2010: An Assessment. Democratization 18(2), 275-310.

Martin, A. D., K. M. Quinn, J. H. Park, and M. J. H. Park (2017). Package MCMCpack.

Mazzuca, S. L. (2010). Access to Power Versus Exercise of Power Reconceptualizing the Quality of Democracy in Latin America. Studies in Comparative International Development 45(3), 334-357.

Médard, J.-F. (2000). L'État et le politique en Afrique. Revue Francaise de science politique 50(4), pages $=849-854)$.

Mkandawire, T. (2001). Thinking About Developmental States in Africa. Cambridge Journal of Economics 25(3), 289-314.

Mkandawire, T. (2015). Neopatrimonialism and the political economy of economic performance in Africa: Critical reflections. World Politics 67(3), 563-612.

Morse, Y. L. (2012). The Era of Electoral Authoritarianism. World Politics 64 (1), 161-198.

O'Donnell, G. (1993). On the State, Democratization and Some Conceptual Problems: A Latin American View with Glances at Some Postcommunist Countries. World Development 21(8), 1355-1369.

Opalo, K. (2012). African elections: Two Divergent Trends. Journal of Democracy 23(3), 80-93.

Pemstein, D., K. L. Marquardt, E. Tzelgov, Y. ting Wang, J. Krusell, and F. Miri (2017). The V-Dem Measurement Model: Latent Variable Analysis for Cross-National and Cross-Temporal Expert-Coded Data. Varieties of Democracy Institute: Working Paper No. 21, 2nd Edition.

Pitcher, A., M. H. Moran, and M. Johnston (2009). Rethinking Patrimonialism and Neopatrimonialism in Africa. African Studies Review 52(1), 125-156. 
Posner, D. N. and D. J. Young (2007). The Institutionalization of Political Power in Africa. Journal of Democracy 18(3), 126-140.

Ross, M. (2006). Is Democracy Good for the Poor? American Journal of Political Science 50(4), 860-874.

Roth, G. (1968). Personal Rulership, Patrimonialism, and Empire-Building in the New States. World politics 20(2), 194-206.

Schatzberg, M. G. (2001). Political Legitimacy in Middle Africa: father, family, food. Indiana University Press.

Schmitter, P. C. (1992). The Consolidation of Democracy and Representation of Social Groups. American Behavioral Scientist 35(4-5), 422-449.

Scott, J. C. (1972). Patron-Client Politics and Political Change in Southeast Asia. American Political Science Review 66(1), 91-113.

Stasavage, D. (2005). Democracy and Education Spending in Africa. American Journal of Political Science 49(2), 343-358.

Stokes, S. C., T. Dunning, M. Nazareno, and V. Brusco (2013). Brokers, voters, and clientelism: The puzzle of distributive politics. Cambridge: Cambridge University Press.

Theobald, R. (1982). Patrimonialism. World Politics 34(4), 548-559.

Van Cranenburgh, O. (2008). Big MenRule: Presidential Power, Regime Type and Democracy in 30 African Countries. Democratization 15(5), 952-973.

Van de Walle, N. (2003). Presidentialism and Clientelism in Africa's Emerging Party Systems. The Journal of Modern African Studies 41(2), 297-321.

VonDoepp, P. (2005). The Problem of Judicial Control in Africa's Neopatrimonial Democracies: Malawi and Zambia. Political Science Quarterly 120(2), 275-301.

Weber, M. (1946). From Max Weber: Essays in Sociology. Translated, edited and with an introduction by HH Gerth and C. Wright Mills. Oxford University Press.

World Bank (2017). World Development Indicators.

Young, C. (2012). The Postcolonial State in Africa: Fifty Years of Independence, 1960-2010. University of Wisconsin Press.

Zolberg, A. R. (1966). Creating Political Order: The Party-States of West Africa. Rand McNally. 